\title{
MANAGEMENT EFFECTIVENESS OF RINJANI-LOMBOK GEOPARK ON GEOTOURISM TRACK
}

\author{
Ayu Puspa Kartika ${ }^{1 *}$, Bambang Hari Wibisono ${ }^{2}$ \\ ${ }^{1}$ Department of Architecture and Planning, Faculty of Engineering, Universitas Gadjah Mada, Yogyakarta, Indonesia \\ ${ }^{2}$ Department of Architecture and Planning, Faculty of Engineering, Universitas Gadjah Mada, Yogyakarta, Indonesia
}

\begin{abstract}
Managing the Geopark involves the integration between several aspects; conservation, education, and the sustainable community economic development. Multistakeholder is responsible for managing the Geopark. To make it effective, the stakeholders should work equally balanced. This study is aimed to evaluate the management effectiveness of Geopark in Geotourism track with specified theme. The method that was used in this study is descriptive quantitative approach, with the help of rating scale to analyze partial scoring and managing, as well as in each aspect and as a whole. This research was done at Rinjani-Lombok Geopark which focused on Geotourism track 2: the Ancient Volcanic Mountains Trail in Sembalun Valley and Geotourism Track 3: The Youngest Volcanic Mountain, Rinjani. The respondents were chosen by non-probability-sampling method, which is purposive sampling. It consists of Geopark management, government, locals, and tourists. As a result, it is shown that the management effectiveness is considered average, and also there are some imbalances found among the aspects mentioned. Educational aspect has the lowest efficiency, while the rests of the aspects are on average level. There are several indicators that influenced in educational aspect, and one of them is caused by the worst management.
\end{abstract}

\section{Keywords:}

Effectiveness, Geopark, Geotourism track, Management

\section{Introduction}

Geological heritage is an important historical record on Earth that has received special attention from UNESCO by building a Geopark through UNESCO Global Geopark (UGG). According to UNESCO (2006), Geopark is a national conservatory area where geological heritages which have unusual beauty, that could be developed as a part of integrated concept such as conservation, education, and local economic growth. UNESCO Global Geopark propose geotourism offerings seeking to deepen the publics' knowledge of geoscience, as well as to promote territorial geosites, cultural sites and regional stories (Justice, 2018). The purpose of Geopark is to explore, develop, and perform integration between geological heritages and conservatory aspects, cultures, as well as invisible heritages (Setyadi, 2012). Geopark could present direct and indirect benefits if it is developed continuously (Yanuar, 2018). As UNESCO (2004) stated, a decent Geopark is based on 3 factors; geo-diversity, bio-diversity, and cultural diversity.

Indonesia is one of the countries that have its geological heritages acknowledged by establishment of UNESCO Global Geopark; Rinjani-Lombok Geopark is one of the examples. This Geopark is confirmed as the national
Geopark in 2013 and as UNESCO Global Geopark in 2018. To support the Geopark, the government formed RinjaniLombok UNESCO Global-Geopark Management Agency, which mainly based on conservatory, education, and sustainable local economic development. One of the geosite potentials, Rinjani National Park, is also as an icon of Rinjani-Lombok Geopark. However, there are some obstacles during the management process; waste problems along the hiking trail because of geotourism activities, determining the ticketing system, the construction of hiking trails, problems of inequality volunteers, and training and development of tourism service providers such as tour guide. Those problems often happened because of social jealousy from Geopark's activities, where managed and run by the higher people (in the management), that leads to locals feel wronged. The problems become more serious when locals only got negative impacts by the garbage produced from Geopark activities (Dowling, 2013). It shows some obstacles to the implementation of presidential regulation no. 9 year 2019, where it is written and explained clearly about the aspects that must be considered in managing Geopark. Hence, this study is aimed to evaluate management effectiveness in 
Rinjani-Lombok Geopark in Geotourism track with specified theme based on the situation explained above.

\section{Literature Review}

Effectiveness is a measurement of the planned objectives achievement in advance. Management effectiveness must be in accordance with the needs and balanced with the role of the surrounding community so as to produce management that has a positive impact in solving social environmental problems (Supriadinata and Goestaman, 2013).

UNESCO (2004) requires that the feasibility of Geopark is assessed based on 3 (three) elements, namely geological diversity, bio diversity, and cultural diversity. The purpose of determining 3 (three) Geopark elements is for the development and improvement of a people's economy based on the principle of protection or conservation of the three elements of diversity. The three elements of diversity must be owned by the Geopark as a condition in its management.

In Indonesia, the management of Geopark is based on Law Number 26 Year 2007 concerning on Spatial Planning which mandates the importance of natural heritage as development capital. In supporting the mandate of the law, the Republic of Indonesia Presidential Regulation No. 9 year 2019 concerning on the Development of Earth Parks (Geopark) was prepared. This regulation explains that the central government and regional governments develop Geopark in accordance with their authority, which in the implementation process involves stakeholders.

Geopark Management refers to the Presidential Regulation Number 9 year 2019 concerning on Earth Parks (Geopark) which can be specifically used as a basis for managing geotourism, as follows:

1. Management and maintenance of the Geopark environment

2. Utilization of geological sites (geo site), geological heritage (geo heritage), geological diversity (geo diversity), biodiversity, and cultural diversity.

3. Development of a monitoring and observation system of geological sites (geo site), geological heritage (geo heritage), geological diversity (geo diversity), biodiversity, and cultural diversity.

4. Implementation of the conservation program of geological sites (geo site), geological heritage (geo heritage), geological diversity (geo diversity), biodiversity, and cultural diversity.

5. Development of education and training

6. Community economic development based on creative economy

7. Socio-cultural preservation

8. Development of tourism destinations

9. Development of amenities and supporting infrastructure for tourism

10. Provision of information on the presence of Geopark

11. Development of Geopark institutions

12. Promotion of the Geopark's scientific value

13. Development of cooperation and active role of Geopark managers

14. Periodic report preparation

\section{Research Method}

The research method used in this study is a descriptive quantitative approach which was assisted by rating scale assessments. Descriptive approach was used to provide an overview of the existing conditions that occur in the management of Geopark while quantitative was used to measure the management effectiveness of the RinjaniLombok Geopark on Geotourism track 2 and Geotourism track 3. Data collection techniques that were used are primary and secondary surveys. The primary survey was conducted using research instruments in the form of interviews and questionnaires. Respondents were selected using a non-probability sampling technique in the form of purposive sampling by selecting respondents through certain considerations. It consists of Geopark management, government, locals, and tourists. The number of samples was calculated using the Slovin method with samples of 170 respondents. The data analysis technique used is a scoring technique that was calculated partially or on each aspect as well as a whole (Ardi, 2017):

a. Partial Effectiveness Value

Partial Effectiveness Value $=\frac{\mathrm{n} \text { Score } \mathrm{X}}{\mathrm{n} \text { Indicator } \mathrm{X}} \times \mathrm{N}$ Indicator

Information:

$\mathrm{nX} \quad=$ Total Score of Aspect $\mathrm{X}$

$\mathrm{n}$ Indicator $\mathrm{X}=$ Number of Indicator Aspect $\mathrm{X}$

$\mathrm{N}$ Indicator $\quad=$ Total Number of Indicator

\section{b. Overall Effectiveness Value}

Overall Effectiveness Value $=\frac{\text { Total Score of All Aspects }}{\text { Number of Aspects }}$

Meanwhile, to determine the indicator score category and the effectiveness category were done by calculating the average value interval, with the following formula.

$$
\text { Interval Value }=\frac{\mathrm{Xmax}-\mathrm{Xmin}}{\mathrm{N}}
$$

Information:

$X \max =$ Maximum value

$X \min =$ Minimum value

$\mathrm{N}=$ Number of categories

\section{Results and Discussions}

\subsection{Description of Geopark Area}

Rinjani-Lombok Geopark is located in Lombok Island, West Nusa Tenggara Province with an area of $\pm 2,800 \mathrm{Km} 2$. The Rinjani-Lombok Geopark region consists of 33 Districts in four Regencies and one City, namely East Lombok Regency, Central Lombok Regency, West Lombok Regency, North Lombok Regency, and Mataram City. Based on An Application Dossier for Membership to UNESCO Global Geopark (2016), Rinjani-Lombok Geopark has a wealth of geo-site which includes 22 geo-diversity sites, 8 biodiversity sites, and 17 cultural diversity sites.

The management of the Rinjani-Lombok Geopark is based on three main pillars of the UNESCO Global Geopark, namely conservation, education, and sustainable community economic development. In managing the Rinjani-Lombok Geopark, four Geotourism tracks are arranged with the aim of facilitating management because each Geotourism track has a management focus based on 
the theme of each track. The preparation of Geotourism track also aims to facilitate the development of geosites as tourist destinations. The four Geotourism tracks include Geotourism track 1: Ancient Volcanic Trail on the West Coast of Lombok Island, Geotourism track 2: Ancient Volcanic Trail in Sembalun Valley, Geo-tourism track 3: The Youngest Volcanic Mountain, Rinjani, and Geotourism track 4: Rinjani Cultural Landscape

This study focuses on evaluating management effectiveness of the Rinjani-Lombok Geopark on Geotourism track 2 and Geotourism track 3. This is based on several factors namely the geo-site potential and the attractiveness of the two pathways which have interconnected history, training and community empowerment on Geotourism track 2 or in the Sembalun Valley which is intended to support the management of geo-site on geotourism track 3 or Mt. Rinjani climbing track, as well as most of the livelihoods of the people of geotourism track 2 in Sembalun Valley depending on the activities of climbing Mount Rinjani which is on Geo tourism track 3.

Geo-tourism track 2 as a whole is located in Sembalun Valley or Sembalun District, East Lombok Regency. The Sembalun Valley is a relic of the ancient volcanic caldera which is now a fertile plain of the Lombok Island agro tourism center and the gate to Mount Rinjani. Geo-sites that were found in Geotourism track 2 include Sembau Hot Springs, Sembalun Valley, Gawir Sesar Pusuk, Sembalun Caldera Wall, Mangku Sakti Waterfall, Aik Kalak Sembalun, Lava Lentih, Mt. Rinjani National Park, East Rinjani KPH, Beleq Sembalun Village, and Gadjah Mada heritage.

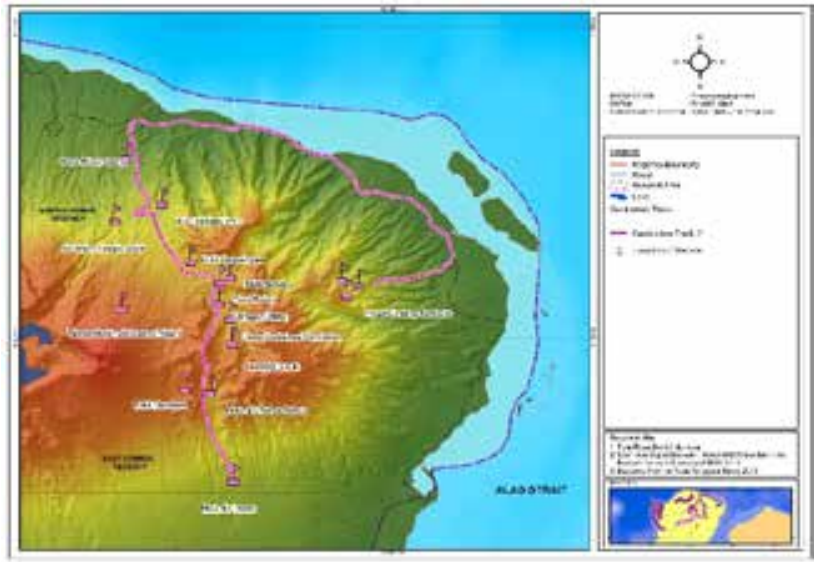

Figure 1. Map of Geotourism Track 2

Meanwhile, Geotourism track 3 is a geotourism track which has geo-site strength from the eruption of Mount Samalas in 1257. On the geotourism track, there is an icon of the Rinjani-Lombok Geopark, Mount Rinjani, which has an altitude of $3762 \mathrm{~m}$ above sea level. In addition, there are also other geosites including the Samalas Caldera, Lake Segara Anak, Mount Barujari, Aik Kalaq, Susu Cave, Sindang Gila and Tiu Kelep Waterfalls, Luka tau Beach, Tebing Beach, Mt. Rinjani National Park, and Mulang Pekelem on Lake Segara Anak.

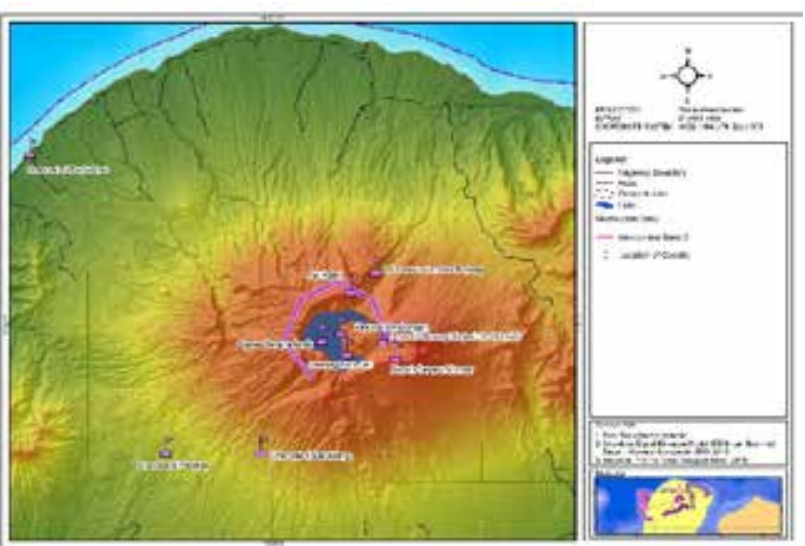

Figure 2. Map of Geotourism Track 3

In an effort to support management, Geopark Management develops Geotourism Product, referred to as Geoproduct. The aim in developing Geoproduct is to increase competitiveness, at the same time to provide large and broad benefits for the community and tourism actors in the selected destination. The development of Geoproduct includes a mechanism for identifying potential geotourism products, determining the theme of geotourism products, developing geotourism programs, and drafting geotourism package. The development of geotourism products is carried out through five activities, namely:

1. Workshop for making geotourism tracks and supporting programs, cooperate with the community, manager of tourist attractions, and related SKPD.

2. Workshop for planning interpretation for the formed geotourism tracks

3. Identifying the needs of the geotourism development program

4. Compilation and trial tour packages

5. Making video tracks and geotourism packages.

Based on these five activities obtained at Geopark, there are four developing Rinjani-Lombok geotourism product. Those are geotour, geoculinary, geosouvenir, and geohomestay. Following are the explanations of each geotourism product.

1. Geotour, Geotour is a geotourism product which was developed through a tour package that combines ttour destination with geological wealth, biological wealth, cultural wealth as well as community social activities as part of tour destinations to be visited by travelers. The development of geotour package is done by increasing information related to Rinjani-Lombok Geopark through the installation of information boards in each attractions as well as through information conveyed by geotour guides who are called interpreter.

2. Geoculinary, Geoculinary is a geotourism product by developing potential local culinary through providing the understanding of geological terms and terms of Rinjani-Lombok Geopark. 
3. Geosouvenir, Geosouvenir is a geotourism product which was developed from local souvenirs in the forms and themes that related to Rinjani-Lombok Geopark.

4. Geohomestay, Geohomestays adalah homestay yang dirancang dengan tema populasi Geopark Rinjani-Lombok yang dapat disewa dengan harga terjangkau. pengembangan geohomestay harus didukung dengan brosur yang berisi informasi terkait Geopark Rinjani-Lombok. Namun, pengembangan geohomestay membutuhkan lebih banyak waktu untuk menggali dan mengumpulkan informasi di lapangan yang digunakan sebagai bahan presentasi terkait Geopark Rinjani-Lombok dan juga relevan dengan lokasi geohomestay. Materi informasi yang telah dikumpulkan kemudian akan ditafsirkan oleh juru bahasa geotour.

\subsection{Management of Geopark Rinjani-Lombok}

Based on Presidential Regulation No. 9 year 2019 concerning on the Earth Park (Geopark) states that the management of Geopark is carried out by the Governor or the Provincial Government if the Geopark area is located in cross-regency / city areas within 1 (one) province. Based on this regulation, the management of the Rinjani-Lombok Geopark is mainly carried out by the Regional Government of West Nusa Tenggara Province. Interested parties in managing the Rinjani-Lombok Geopark as follow:

a. Government

The government has a role in making policies related to the management of the Rinjani-Lombok Geopark. The government consists of the West Nusa Tenggara Provincial Government and the district / city regional governments, namely the Mataram Regional Government, the West Lombok Regency Government, the East Lombok Regency Government, the Central Lombok Regency Government, and the North Lombok Regency Government.

b. Private Parties

Private parties are those who have the capital to be invested in the Rinjani-Lombok Geopark Area such as hotel ownership in the Sembalun Valley region.

c. Community

Local communities in the Rinjani-Lombok Geopark delineation work in government agencies, in private sectors / as entrepreneur, and unemployed. It is planned that the unemployed have their own businesses such as street vendors at the Geosite location, becoming porters / guides.

In supporting the management of the Rinjani-Lombok Geopark, Rinjani-Lombok UNESCO Global Geopark Management Agency (BP-RLUGG) was formed, which is the policy coordination and management agency for the regions in the Rinjani-Lombok Delegation of UNESCO Global Geopark. The UNESCO Global Geopark Management Agency has the following organizational structure:

1. Advisory Board: Governor of West Nusa Tenggara Province

2. Director Board: Regional Secretary of West Nusa Tenggara Province

3. Head of the OPD
4. Implementing Agency:

a. General Manager

b. Manager of Community Empowerment and Role of Women Enhancement

c. Manager of Conservation, Disaster Mitigation, and Climate Change

d. Manager of Education and Culture

e. Manager of Research and Development and Institutions Cooperation

f. Manager of Marketing and Creative Economy Development

g. Manager of Geotourism and Trekking

5. Secretariat:

a. Head of the Secretariat

b. Administration Sector

c. Financial Sector

d. General sector

The management of Rinjani-Lombok Geopark has a vision that is "The realization of Rinjani-Lombok Geopark that is sustainable and internationally competitive". The vision is realized through five missions, which are as follows:

1. Preserving the diversity of geological resources, cultural uniqueness, and the richness of living natural resources.

2. Enhancing community welfare through strengthening the role of the community in managing Geopark, expanding business opportunities, and increasing community and regional income.

3. Building world-class tourism destinations (Geosite) that uphold social, cultural, and legal norms.

4. Enhancing the community through increasing knowledge and geopark understanding and increasing awareness of nature and cultural conservation.

5. Building professional, integrated, and sustainable governance to ensure the realization of sustainable integration of Geopark development.

Regional policies that support the management of the Rinjani-Lombok Geopark include some aspects as follows:

1. Mataram Metro and Senggigi - 3 Gili is a Provincial Strategic Area in accordance with Regional Regulation No. 3 year 2010 concerning on Spatial Planning for West Nusa Tenggara Province years 2009-2029

2. Part of Rinjani-Lombok Geopark Area is a part of the strategic area of North Lombok Regency, East Lombok Regency, and Central Lombok Regency.

3. Rinjani Area as a National Strategic Area and in the Provincial Spatial Layout Plan with the Concept of LECI (Lombok as Eco City Island) in developing Lombok Island.

4. Lemor as a Conservation Area with a Special Purpose as a Botanical Garden in Lombok.

5. The Geopark Region is one of the special locations for the program to strengthen sustainable environmental management as stipulated in the West Nusa Tenggara 
Province Medium Term Regional Development Plan years 2018-2023 (Land Forest Rehabilitation in the West Rinjani KPH and Tastura Areas)

6. Gili Sulat and Gili Petagan are Regional Marine Conservation Areas in East Lombok Regency)

Based on the management structure and supporting policies, the activities that have been carried out by the Regional Government in this case are the Rinjani-Lombok UNESCO Global Geopark Managament Agency together with partners until 2019 including:

1. Strengthening the accessibility track to geosites of the Rinjani-Lombok Geopark. At present the condition of the main connecting road is $95 \%$ good.

2. Strengthening geopark information with thematic information board branding at each site.

3. Building facilities at the geopark site including toilets, shelters, shanties, and parking.

4. Strengthening Geoproducts through mentoring and coaching BP-RLUGG working groups that cooperate with BNI (CSR BNI).

5. Socializing Geopark to the public.

6. Giving education related to geopark to schools (elementary school, junior high school, and senior high school), Islamic boarding schools, and universities.

7. Making Rinjani-Lombok Geopark Guidelines book.

8. Strengthening policies, namely the Draft Governor Regulation concerning on Geopark Institution and the Draft Regional Regulation concerning on RinjaniLombok Geopark Governance.

9. Training for Interpreter and certification for geotourism interpreter

10. Host of the 2019 Asia Pacific Geopark Network (APGN)

11. Application of online booking for prospective climbers of Mount Rinjani
12. Establishment of Rinjani Clean Task Force as an alternative waste solution on Mount Rinjani.

\subsection{Score Calculation of Management Aspect and Determination of Indicator Categories}

The score calculation and the determination of indicator categories are carried out in each aspect of the research, namely aspects of conservation efforts, educational efforts, efforts to develop a sustainable community economy and institutional management. The first step is to calculate the total score of the indicators obtained from the results of the questionnaire assessment by 170 respondents, and then each total score of the indicators is summed to determine the total score of each aspect of management.

After knowing the total score of the indicator in the first stage, the indicator rating category is determined, by previously determining the average value interval as follows.

$$
\text { Interval Value }=\frac{680-0}{3}=226,67
$$

Information:

$X \max =$ Maximum indicator value of $680(4 \times 170)$

Xmin = Minimum indicator value of $0(0 \times 170)$

$\mathrm{N}=$ Number of 3 level categories (high, medium, and low)

Based on the calculation of the average value interval, the following three categories of indicator rating intervals are obtained:

a. Indicators is a good management, if the total score reaches $453.36-680$

b. Indicator is a quite good management, if the total score reaches 226.68 - 453.35

c. Indicators is a poor management, if the total score reaches 0 - 226.67

Following are the results of calculating the scores and determining the indicator categories for each evaluation aspect of the management effectiveness of the RinjaniLombok Geopark on Geotourism track 2 and Geotourism track 3.

Table 1 Score Calculation of Management Aspect and Determination of Indicator Categories

\begin{tabular}{|c|c|c|c|c|c|}
\hline No. & Sub Aspect & Indicator & $\begin{array}{c}\text { Total } \\
\text { Score of Each } \\
\text { Indicator }\end{array}$ & $\begin{array}{l}\text { Interval Indicator } \\
\text { category }\end{array}$ & $\begin{array}{l}\text { Indicator } \\
\text { Category }\end{array}$ \\
\hline \multicolumn{6}{|c|}{ Conservation Efforts } \\
\hline \multirow{4}{*}{1} & \multirow{4}{*}{$\begin{array}{l}\text { Environmental } \\
\text { management and } \\
\text { maintenance }\end{array}$} & $\begin{array}{l}\text { 1. The availability of land to accommodate } \\
\text { activities (including tourism, conservation, } \\
\text { and supporting facilities and infrastructure) }\end{array}$ & 419 & \multirow{5}{*}{$\begin{array}{l}\text { Good }=453.36-680 \\
\text { Average }=226.68- \\
453.35 \\
\text { Poor }=0-226.67\end{array}$} & Average \\
\hline & & $\begin{array}{l}\text { 2. The readiness of managers, communities, } \\
\text { and tourists in the event of a disaster } \\
\text { (including the preparation of pre, during, } \\
\text { and post disaster management plans, } \\
\text { evacuation tracks, and evacuation sites)) }\end{array}$ & 390 & & Average \\
\hline & & $\begin{array}{l}\text { 3. The commitment of managers, } \\
\text { communities, and tourists in managing } \\
\text { environmental impacts such as garbage } \\
\text { from tourism activities }\end{array}$ & 301 & & Average \\
\hline & & $\begin{array}{l}\text { 4. The firmness of management in giving } \\
\text { sanctions to parties who violate } \\
\text { environmental management }\end{array}$ & 311 & & Average \\
\hline 2 & $\begin{array}{l}\text { Implementation of } \\
\text { conservation } \\
\text { programs }\end{array}$ & $\begin{array}{l}\text { 5. The commitment of managers, } \\
\text { communities, and tourists in protecting } \\
\text { natural geological elements and ecosystems }\end{array}$ & 349 & & Average \\
\hline
\end{tabular}




\begin{tabular}{|c|c|c|c|c|c|}
\hline \multirow[t]{4}{*}{ No. } & \multirow[t]{4}{*}{ Sub Aspect } & Indicator & \multirow{2}{*}{$\begin{array}{c}\begin{array}{c}\text { Total } \\
\text { Score of Each } \\
\text { Indicator }\end{array} \\
\\
333\end{array}$} & \multirow[t]{4}{*}{$\begin{array}{l}\text { Interval Indicator } \\
\text { category }\end{array}$} & \multirow{2}{*}{$\begin{array}{r}\text { Indicator } \\
\text { Category }\end{array}$} \\
\hline & & $\begin{array}{l}\text { 6. The clarity in determining the boundaries of } \\
\text { conservation and tourism areas made by the } \\
\text { manager }\end{array}$ & & & \\
\hline & & $\begin{array}{l}\text { 7. The firmness of management in giving } \\
\text { sanctions to those who violate conservation } \\
\text { regulations }\end{array}$ & 328 & & Average \\
\hline & & $\begin{array}{l}\text { 8. The commitment of the manager in making } \\
\text { periodic reports by involving the community } \\
\text { related to the management of the Geo park } \\
\text { area }\end{array}$ & 280 & & Average \\
\hline \multicolumn{3}{|c|}{ Total Score of Conservation Efforts } & 2.711 & & \\
\hline \multicolumn{6}{|c|}{ Educational Efforts } \\
\hline & \multirow{3}{*}{$\begin{array}{l}\text { The Development of } \\
\text { education and } \\
\text { training and the } \\
\text { development of } \\
\text { science }\end{array}$} & $\begin{array}{l}\text { 1. The frequency of procurement of } \\
\text { adventurous adventure activities } \\
\text { (adventuring) }\end{array}$ & 233 & \multirow{11}{*}{$\begin{array}{l}\text { Good }=453,36-680 \\
\text { Average }=226.68- \\
453.35 \\
\text { Poor }=0-226.67\end{array}$} & Average \\
\hline & & $\begin{array}{l}\text { 2. The commitment of managers in facilitating } \\
\text { learning or research activities to study } \\
\text { geological landscapes (/earning) }\end{array}$ & 200 & & Poor \\
\hline & & $\begin{array}{l}\text { 3. The commitment of the manager and the } \\
\text { community in facilitating interaction } \\
\text { between the community and tourists to be } \\
\text { able to exchange knowledge (enriching) }\end{array}$ & 237 & & Average \\
\hline \multirow{4}{*}{2} & \multirow{4}{*}{$\begin{array}{l}\text { Socio-cultural } \\
\text { preservation }\end{array}$} & 4. The frequency of procuring cultural events & 198 & & Poor \\
\hline & & $\begin{array}{l}\text { 5. The commitment of managers and } \\
\text { community in preserving local social and } \\
\text { cultural activities as an element of } \\
\text { education }\end{array}$ & 210 & & Poor \\
\hline & & $\begin{array}{l}\text { 6. Community understanding when their social } \\
\text { activities are used as research objects (e.g. } \\
\text { growing onions, strawberries, and } \\
\text { vegetables as research objects) }\end{array}$ & 309 & & Average \\
\hline & & $\begin{array}{l}\text { 7. The conformity between prevailing norms or } \\
\text { customary rules and Geopark management } \\
\text { plans (e.g. customary awig-awig rules) }\end{array}$ & 247 & & Average \\
\hline \multirow{4}{*}{3} & \multirow{4}{*}{$\begin{array}{l}\text { Management of } \\
\text { geological } \\
\text { information }\end{array}$} & $\begin{array}{l}\text { 8. The availability of a geological information } \\
\text { center }\end{array}$ & 259 & & Average \\
\hline & & $\begin{array}{l}\text { 9. The availability of an integrated information } \\
\text { system }\end{array}$ & 243 & & Average \\
\hline & & 10. The availability of Geopark museum & 157 & & Poor \\
\hline & & $\begin{array}{l}\text { 11. The quality of information related to } \\
\text { Geopark }\end{array}$ & 198 & & Poor \\
\hline \multicolumn{2}{|c|}{ Total Score of Educational Efforts } & & 2.491 & & \\
\hline
\end{tabular}

Sustainable Community Economic Development

1. The level of providing new jobs after the existence Geopark management 302

Average

2. The level of employment after the existence 289

Community Geopark management

Economic

3. The increasing of community income after 350

Development based

creative economy the existence Geopark management

4. The frequency of training related to the 302 development of the creative economy

5. The quantity of the community trained in developing the creative economy

Good $=453.36-680$

The level of uniqueness or scarcity of the

435

Average $=226.68-$ 453.35 attractions offered

Poor $=0-226.67$

The level of originality of the tourism object by not adopting a development model that is different

2 Development of from the original value (the original condition of associated with the cultural beauty of the Geopark, 


\begin{tabular}{|c|c|c|c|c|c|}
\hline No. & Sub Aspect & Indicator & $\begin{array}{c}\text { Total } \\
\text { Score of Each } \\
\text { Indicator }\end{array}$ & $\begin{array}{l}\text { Interval Indicator } \\
\text { category }\end{array}$ & $\begin{array}{l}\text { Indicator } \\
\text { Category }\end{array}$ \\
\hline & & $\begin{array}{l}\text { The Increasing number of tourist visits after } \\
\text { Geopark management }\end{array}$ & 418 & & Average \\
\hline \multirow{3}{*}{3} & \multirow{3}{*}{$\begin{array}{l}\text { Development of } \\
\text { Geopark supporting } \\
\text { facilities and } \\
\text { infrastructure }\end{array}$} & $\begin{array}{l}\text { The quality of amenities supporting Geopark } \\
\text { services (e.g. places of worship, toilets, parking, } \\
\text { etc.) }\end{array}$ & 345 & & Average \\
\hline & & $\begin{array}{l}\text { The quality of accommodation services supporting } \\
\text { Geopark (e.g. hotels, guesthouses, restaurants } \\
\text { etc.) }\end{array}$ & 452 & & Average \\
\hline & & $\begin{array}{l}\text { The quality of accessibility on Geotourism track } \\
\text { and accessibility to geo site }\end{array}$ & 334 & & Average \\
\hline \multicolumn{3}{|c|}{ Total Score of Sustainable Community Economic Development } & 4.558 & & \\
\hline \multicolumn{6}{|c|}{ Institutional Management } \\
\hline \multirow{5}{*}{1} & \multirow{5}{*}{$\begin{array}{l}\text { Institutional } \\
\text { development }\end{array}$} & $\begin{array}{l}\text { The clarity in the preparation of the institutional } \\
\text { structure of the manager and the community }\end{array}$ & 281 & \multirow{9}{*}{$\begin{array}{l}\text { Good }=453.36-680 \\
\text { Average }=226.68- \\
453,35 \\
\text { Poor }=0-226.67\end{array}$} & Average \\
\hline & & $\begin{array}{l}\text { Community involvement in the institutional } \\
\text { structure }\end{array}$ & 262 & & Average \\
\hline & & $\begin{array}{l}\text { The suitability of manager and community roles in } \\
\text { accordance with the main tasks and functions of } \\
\text { the institutional structure }\end{array}$ & 299 & & Average \\
\hline & & $\begin{array}{l}\text { The procurement frequency of training programs } \\
\text { for communities related to Geopark management }\end{array}$ & 269 & & Average \\
\hline & & $\begin{array}{l}\text { The frequency of socialization by the management } \\
\text { to the public regarding Geopark management }\end{array}$ & 291 & & Average \\
\hline \multirow{2}{*}{2} & \multirow{2}{*}{$\begin{array}{l}\text { Promotion of the } \\
\text { geotourism scientific } \\
\text { value }\end{array}$} & $\begin{array}{l}\text { The frequency of promotional activities carried } \\
\text { out by managers and the community }\end{array}$ & 339 & & Average \\
\hline & & $\begin{array}{l}\text { The innovations made by managers and the public } \\
\text { in promoting Geopark objects }\end{array}$ & 315 & & Average \\
\hline \multirow{2}{*}{3} & \multirow{2}{*}{$\begin{array}{l}\text { Development of } \\
\text { cooperation and } \\
\text { active role of } \\
\text { managers }\end{array}$} & $\begin{array}{l}\text { The cooperation between management and the } \\
\text { government }\end{array}$ & 274 & & Average \\
\hline & & $\begin{array}{l}\text { The cooperation between managers and NGOs / } \\
\text { private sectors }\end{array}$ & 254 & & Average \\
\hline \multicolumn{3}{|c|}{ Total Score of Institutional Management } & 2.584 & & \\
\hline
\end{tabular}

\subsection{The Calculation of Partial and Overall Effectiveness Rating Value}

After knowing the total effectiveness score in each aspect of the study, the next step is to conduct an evaluation of the effectiveness categories partially or on each aspect and the overall management effectiveness categories of the Rinjani-Lombok Geopark on Geotourism Track 2: Ancient Volcanic Mountains Trail in Sembalun Valley and the Geotourism Track 3: The Youngest Volcanic Mountain, Rinjani.

The first step taken in assessing the effectiveness category is to calculate the average value interval to determine the class or category of effectiveness, with the results of the calculation as follows:

$$
\text { Interval Value }=\frac{27.880-0}{3}=9.293
$$

Information:

Xmax $=$ Maximum value of Geopark management effectiveness of $27,880(4 \times 41 \times 170)$

$\mathrm{Xmin}=$ Minimum value of Geopark management effectiveness of $0(0 \times 41 \times 170)$
$\mathrm{N}=$ Number of 3 levels category (high, moderate, and low)

Based on the calculation of the average interval, the following three effectiveness category intervals are obtained:

a. Geopark management effectiveness is high if the total score reaches $18,588-27,881$

b. Geopark management effectiveness is moderate, if the total score reaches $9,294-18,587$

c. Geopark management effectiveness is low, if the total score reaches $0-9,293$

After obtaining the calculation results of the average value interval and effectiveness category, the next step is to calculate the effectiveness value partially and overall as well as determine the effectiveness category of each aspect and the effectiveness category of the Rinjani-Lombok Geopark on Geotourism track 2 and Geotourism track 3. The formula used to calculate the value of effectiveness partially and as a whole based on research method.

The results of calculating the value of management effectiveness and management categories partially and as a whole can be seen in Table 2 as follows.

Table 2. Calculation of Effectiveness Values and Effectiveness Categories

\begin{tabular}{clccccc}
\hline No & \multicolumn{1}{c}{ Aspect } & $\begin{array}{c}\text { Number of } \\
\text { Indicator }\end{array}$ & Total Score & $\begin{array}{c}\text { Effectiveness } \\
\text { Value }\end{array}$ & $\begin{array}{c}\text { Effectiveness } \\
\text { Category Intervals }\end{array}$ & $\begin{array}{c}\text { Effectiveness } \\
\text { Category }\end{array}$ \\
\hline 1 & $\begin{array}{l}\text { Conservation } \\
\text { Efforts }\end{array}$ & 8 & 2,711 & $13,893.88$ & High $=18,588-27,881$ & Average \\
\hline 2 & Educational Efforts & 11 & 2,491 & $9,284.64$ & Average $=9,294-$ & Low \\
\hline
\end{tabular}




\begin{tabular}{|c|c|c|c|c|c|c|}
\hline 3 & $\begin{array}{l}\text { Sustainable } \\
\text { Community } \\
\text { Economic } \\
\text { Development }\end{array}$ & 13 & 4,588 & $14,469.85$ & $\begin{array}{l}18,587 \\
\text { Low }=0-9,293\end{array}$ & Average \\
\hline 4 & $\begin{array}{l}\text { Institutional } \\
\text { Management }\end{array}$ & 9 & 2,584 & $11,771.56$ & & Average \\
\hline \multicolumn{4}{|c|}{ Total of Effectiveness Value } & $12,354.98$ & & Average \\
\hline
\end{tabular}

The management effectiveness of Rinjani-Lombok Geopark on Geotourism track 2 and Geotourism track 3 are included in the average effectiveness category with an effectiveness value of 12,354.98. Then when viewed based on the management effectiveness in each aspect, aspects of conservation efforts, sustainable community economic development, and institutional management are included in the category of average effectiveness with the respective effectiveness values of $13,893.88$ for conservation efforts, $14,469.85$ for sustainable community economic development, and 11,771,56 for institutional management aspects. Meanwhile, aspect of educational efforts is included in the low effectiveness category with an effectiveness value of 9,284.64.

The management effectiveness of Rinjani-Lombok Geopark on Geotourism track 2 and 3 are included in the average effectiveness category because there are no indicators of management that are categorized as good, but there are management indicators that are going well enough and there are indicators that experience some problems, so that the indicators do not show optimal results or in the poor category. These indicators include:

1. Commitment of managers in facilitating learning activities or research to study geological landscapes (learning)

2. Frequency of procuring cultural events

3. Commitment of managers and the community in preserving local social and cultural activities as an element of Education

4. Availability of Geopark museum

5. Quality of information related to Geopark

\section{Conclusion}

Management of Geopark area is an area management with a special utilization category that involves many parties. Geopark management should be carried out by integrating aspects of conservation, education, sustainable community economic development, and institutional management. But in its implementation of the management of the Rinjani-Lombok Geopark on Geotourism track 2: Ancient Volcanic Mountains Trail in Sembalun Valley and Geotourism track 3: the Youngest Volcanic Mountain, Rinjani, the management of these aspects do not run in a balanced way. Educational efforts are an ineffective management concept in Geotourism track 2 and Geotourism track 3. There are five indicators that are less successful, namely the commitment of managers in facilitating learning or research activities to study geological landscapes, the frequency of procuring cultural events, the commitment of managers and the community in preserving local social and cultural activities as an element of education, the availability of Geopark museums, and the quality of information related to Geopark. This study also adds aspect of institutional management to evaluate the effectiveness with the results it is included in the average effectiveness category. This is in line with Oktariadi's (2016) explanation that Geopark management is carried out with multi-stakeholders or involves many parties and sectors.

This research can be used as an illustration in evaluating the indicators management of Rinjani-Lombok Geopark and is used as a basis for planning an increase in indicators that are still in the poor category. Then, for further research, it can conduct further research on the comparison of Geopark management in each Geotourism track because each Geotourism tracks has different themes and problems, and to find a comparison of the effectiveness of each management concept with different themes and characteristics of the community.

\section{References}

An Application Dossien for Membership to UNESCO Global Geoparks 2016. Submitted by Indonesian National Commission for UNESCO.

Ardi, W. F. (2017) Effectiveness of City Park 1 BSD as a Public Green Open Spacein The Urban Area BSD City, South Tangerang City. Journal of RUANG, Volume 3 Number 1, Pages 11-20.

Dowling, Ross K. (2013) Global Geotourism-An Emerging Form of Sustainable Tourism. Czech Journal of Tourirm, 2(2), 57-79. Doi: 10.2478/cjot-2013-0004.

Justice, Sophie Catherine. (2018) UNESCO Global Geoparks, Geotourism and Communication of the Earth Sciences: A Case Study in the Chablais UNESCO Global Geopark, France. Geosciences 2018, 8, 149; doi:10.3390/geosciences8050149.

Presidential Regulation Number 9 year 2019 concerning on Earth Parks (Geopark)

Setyadi, Dhika Anindhita. (2012) Studi Komparasi Pengelolaan Geopark di Dunia untuk Pengembangan Pengelolaan Kawasan Cagara Alam Geologi Karangsambung. Biro Penerbit Planologi UNDIP, 1 (1), 77-82.

Supriadinata, W and Goestaman, I. (2013) Analisis Efektivitas Corporate Social Responsibility (CSR) dalam Menyelesaikan Masalah Sosial Lingkungan Perusahaan. Journal of Calyptra, Volume 2-1, Pages 1-13.

Yanuar, Yerry. (2018) Keberlanjutan Pengembangan Geopark Nasional Ciletuh Pelabuhan Ratu dalam Perspektif Infrastruktur. Jurnal Sosek Pekerjaan Umum, Vol. 10.1, April 2018, Pages 6472.

http://www.unesco.org/new/en/natural-sciences/environment/earthsciences/unesco-global-geoparks/ (accessed on December 23, 2019) https://rinjanigeopark.com/ (accessed on April 5, 2020) 